\title{
Mitigation Heat Stress on Tomato Plant by Shading and Fogging System: Influence Microclimate, Fruit Set, Yield and Physiological Disorders
}

\author{
M. A. Sharaf-Eldin \\ Kafrelsheikh University, Faculty of Agriculture, Department of \\ Horticulture, Kafrelsheikh, Egypt.
}

\begin{abstract}
7 HE IMPACT of heat stress on tomato plant (Lycopersicon esculentum MILL.) during the late summer season was studied in the International Protected Cultivation Centre, Kafrelsheikh University, Egypt. The plants were grown in the open field and in a shaded house covered by white net providing $35 \%$ shading. The shaded house was divided into three groups, two of them grown under two fogging systems and the third one was isolated without fogging. The fogging system was operated to work $10 \mathrm{~min} / \mathrm{h}$ or $20 \mathrm{~min} / \mathrm{h}$. According to the climatic data, the fogging system was adjusted to only work during the peak temperature period of the day (10 am - 4 $\mathrm{pm})$. The maximum temperature was recorded at $2 \mathrm{pm}$ in the open field which exceeded $37^{\circ} \mathrm{C}$ during the peak flowering and fruit set period. While the temperature was extremely high in the open field, the $\mathrm{RH} \%$ was extremely low which reached to $39 \%$ at $2 \mathrm{pm}$. The results indicated that the average monthly of maximum temperature reduced $1.8{ }^{\circ} \mathrm{C}$ by shading and $4.5^{\circ} \mathrm{C}$ by fogging under shading. Inside the shaded house, the RH $\%$ increased by $10 \%$ and the fogging added more $16 \%$ during the period of $10 \mathrm{am}-4 \mathrm{pm}$. All studied treatments mitigated heat stress on tomato plant and decreased fruit physiological disorders. Improving the microclimate inside the shaded house by fogging systems resulted in higher fruit set percentage, fruit weight and total and marketable yields than those obtained from the open field. The main fruit disorders were cracking, sunscald, blossom end rot, puffiness, internal white tissues, blotchy ripening and cat face, respectively. The most effective treatment was the use of fogging system for $20 \mathrm{~min} / \mathrm{h}(10 \mathrm{am}-4 \mathrm{pm})$ under shaded house for high fruit yield and less physiological disorders during the late summer season.
\end{abstract}

Keywords: Tomato, Heat stress, Shaded house, Fogging system, Fruit set, Yield, Physiological disorders.

One of the critical problems of climatic changes is the global warming which causes many risks for all human life including food security. Mediterranean region has been identified as a possible climate-change "hot spot" (Alessandri et al., 2014). Mediterranean climate is characterized by high summer temperatures, high solar radiation, low relative humidity and limited water resources. The global warming was expected to increase in the next years with great impact on nature and ecosystems including plant production and quality (Mahato, 2014). Tomatoes as one of the most important vegetables in the world 
are negatively affected by stressful temperatures, which in turn affect yield and product quality. Harel et al. (2014) suggested that temperatures of $2.5^{\circ} \mathrm{C}$ above the optimal mean daily temperature $\left(25^{\circ} \mathrm{C}\right)$ reduced the ability of the plant to reach its potential fruit set by up to $40 \%$. Sato et al. (2000) reported that $32 / 26$ ${ }^{\circ} \mathrm{C}$ day/night temperatures had negative effect on release of pollen grains, fruit set and fruit production. A reduction in tomato yields with increase incidences of fruit physiological disorders such as blossom-end rot, cracking, puffiness and sunscald causing significant loss was also noted under heat stress in the open field (Milenković et al., 2012 and Shehata et al., 2013).

One strategy to alleviate temperature stress on the plant is using heat/cool systems under greenhouses modifying the microclimate to be suitable for plant production (El-Aidy and Sharaf-Eldin, 2015). Although these systems have favorable effect on plant production, they are still expensive. Another strategy to reduce solar radiation and air temperature as well as increasing relative humidity with low cost is shading (Zaki et al., 2014). It is reported that shading increased tomato growth, yield and quality compared to the open field under the late summer season (Shehata et al., 2013 and El-Bassiony et al., 2014). But it needs to add high efficiency system to control the temperature and $\mathrm{RH}$ at the peak periods during afternoon time.

Fogging systems have been suggested as a cooling method to mitigate the adverse effects of high evaporation and excess temperatures (FAO, 2013). Fog systems are based on spraying water in the fog range, in the form of small droplets 2- $60 \mu \mathrm{m}$ in diameter, in order to increase the water surface in contact with air (Montero, 2006). It is postulated that the fogging system offers a better balance between production and nutritional quality (Leyva et al., 2014). Fogging system inside the screenhouse showed good performance in terms of radiation with a percentage reduction of incident radiation on the crop of $18 \%$ and a mean reduction of maximum VPD (Vapor Pressure Deficit) values of - $0.4 \mathrm{KPa}$, compared with the unfogging treatment (Leyva et al., 2013). Leyva et al. (2015) reported that using fogging system on cherry tomato grown under screenhouse reduced incident radiation $30-37 \%$, while increased relative humidity by $16-$ $20 \%$ avoiding incident of physiological stress that affect yield and final quality.

From monitoring climate data in the north River Nile Delta, high stressful temperature and low RH for tomato fruit set and quality occur between 10 am and $4 \mathrm{pm}$ during the late summer season. In this study, the traditional cultivation in the open field was compared with cultivation in a shaded house provided with different fogging techniques during the late summer season in order to evaluate its influence on microclimate, tomato fruit set, yield and physiological disorders.

\section{Material and Methods}

The experiments were carried out in the International Protected Cultivation Centre, Faculty of Agriculture, Kafrelsheikh Univ., Egypt in a silty-clay soil

Egypt. J. Hort. Vol. 42, No. 2 (2015) 
(7.8 $\mathrm{pH}, \mathrm{EC} 1.38 \mathrm{ds} \mathrm{m}^{-1}$ and $1.8 \%$ organic matter) during the late summer seasons of 2013 and 2014 on tomato crop (Lycopersicon esculentum Mill.) cv. 023. Five weeks old seedlings were transplanted on $1^{\text {st }}$ June with plant density of 2.7 plant $\mathrm{m}^{-2}$ and the drip irrigation system was applied. The plants were grown in both the open field and shaded net house. The net house orientation was north/south with natural ventilation and had 3-4 m height with $1200 \mathrm{~m}^{-2}$ total ground area. White mesh insect proof net with $35 \%$ shading level were used as a cover for the net house. Fogging system was set up to produce fogging under 405 $\mathrm{KPa}$ pressure. The fog lines were spaced at $100 \mathrm{~cm}$ below the house roof. Plastic sheets were hanged vertically inside the net house as a hail to prevent overlapping. Each experimental unit consisted of three rows with $15 \mathrm{~m}$ length. The common agricultural practices were managed for fertilization, pest and irrigation managements. Minimum, maximum and average temperature and RH\% were monitored by RH/Temp data loggers at $50 \mathrm{~cm}$ height above the plant canopy and the sensors were shielded to avoid direct sun light. The temperature and RH\% were registered hourly during the all season. However, they presented during one day of the peak flowering and fruit set $\left(26^{\text {th }}\right.$ July). The monthly averages of the whole season were also presented.

The plants were arranged in four treatments as follow:

- Open field planting without fogging system (OF).

- $\quad$ Shaded net house without fogging system (S).

- $\quad$ Shaded net house with fogging system operating from $10 \mathrm{pm}$ to $4 \mathrm{pm}$ for 10 $\mathrm{min} / \mathrm{h}$ in a rate of $6 \mathrm{~S} / 36 \mathrm{~S}(\mathrm{SF} 1)$.

- $\quad$ Shaded net house with fogging system operating from $10 \mathrm{pm}$ to $4 \mathrm{pm}$ for 20 $\mathrm{min} / \mathrm{h}$ in a rate of $12 \mathrm{~S} / 36 \mathrm{~S}(\mathrm{SF} 2)$.

Full mature pink fruits from all the plants were picked to estimate total and marketable yields per plant $(\mathrm{kg})$, average fruit weight $(\mathrm{g})$ and fruit set percentage (taken during 2 weeks of the peak flowering and fruit set period). All fruits were sorted every picking to determine the percentage of the next disorders.

- Cracking: radial or concentric cracking.

- Sunscald: yellow, sunken and/or wrinkled areas.

- Blossom end rot (BER): water-soaked areas at or near the blossom end.

- Puffiness: bloated and flat-sided and/or inside cavities that lack the seed gel.

- Internal white tissue (IWT): internal white hard areas in the outer walls and/or in cross-wall, without outer symptoms (was taken in random 10 fruits from each treatment).

- Blotchy ripening: outer uneven ripening or yellow shoulders.

- Cat face shape: deep indentations in the blossom end.

The incident of physiological disorders was expressed individually as average of all pickings. 
Complete block randomized design in three replicates was conducted. Data were analyzed by one-way analysis of variance using statistical software SPSS 18.0 for windows. Significant differences in mean values were evaluated by Tukey test at $(\mathrm{p}<0.05)$.

\section{Climate data}

\section{Results}

The temperature and RH\% were registered hourly at $26^{\text {th }}$ July were shown in (Fig. $1 \& 2$ ). High increase in air temperature was noticed between $10 \mathrm{am}$ and $4 \mathrm{pm}$ at ambient air (Fig. 1). The values ranged between 34.2 and $39.4{ }^{\circ} \mathrm{C}$ at 2013 season and between 32.7 and $37.2^{\circ} \mathrm{C}$ at 2014 season. The maximum temperatures were recorded at $2 \mathrm{pm}$ in the open field during the both studied seasons. The treatments could be arranged from the lower to the higher temperatures as SF2 (shading plus fogging $20 \mathrm{~min} / \mathrm{h}$ ) > SF1 (Shading plus fogging $10 \mathrm{~min} / \mathrm{h}$ ) > S (shading) $>\mathrm{OF}$ (open field). However, SF2 recorded only $2{ }^{\circ} \mathrm{C}$ lower than the open field of the all day average temperature, it decreased $6.8^{\circ} \mathrm{C}$ during the peak period $(10 \mathrm{am}-4 \mathrm{pm})$. The daily average temperature decreased $0.7{ }^{\circ} \mathrm{C}$ in $\mathrm{S}$ treatment and $1.5{ }^{\circ} \mathrm{C}$ in $\mathrm{SF} 1$ while they decreased $3{ }^{\circ} \mathrm{C}$ and $5.5{ }^{\circ} \mathrm{C}$ during the peak period, respectively. These results indicate that providing the shaded house by fogging system operating 20 $\mathrm{min} / \mathrm{h}$ was the most effective treatment for controlling the raise temperature during the peak periods.

While the temperature was extremely high in the open field during the peak periods (10 am - 4 pm), the RH\% was extremely low (Fig. 2). The RH\% gradually decreased from 6 am to 2 pm which reached to the minimum (38$41 \%$ ) at $2 \mathrm{pm}$ then gradually increased until 6 am which reached to the maximum values (87 - 98\%). In the open field from 10 am to $4 \mathrm{pm}$, the RH\% ranged from 38 to $56 \%$ in 2013 season and from 41 to $53 \%$ in 2014 season. Comparing the shaded house with the open field during the peak period (10am - 4pm), the RH\% increased by $9-13 \%-8-11 \%$ in 2013 and 2014, respectively. At the same period, the use of fogging system under the shaded house added 11-18\% to those obtained in the shaded housed without fogging. Increasing operating time of the fogging system from 10 to $20 \mathrm{~min} / \mathrm{h}$ increased the RH\% by $4-9 \%$ as average of the two seasons. Almost the RH\% did not differ inside the shaded house either with or without fogging (off time) at the other day times. Whereas, the RH\% decreased 1-15\% under the shaded housed at night and early morning comparing with the open field. In a brief, during the peak period, the $\mathrm{RH} \%$ increased inside the shaded house $10 \%$ without fogging, $18.7 \%$ with $10 \mathrm{~min} / \mathrm{h}$ fogging and $26 \%$ with $20 \mathrm{~min} / \mathrm{h}$ fogging. 


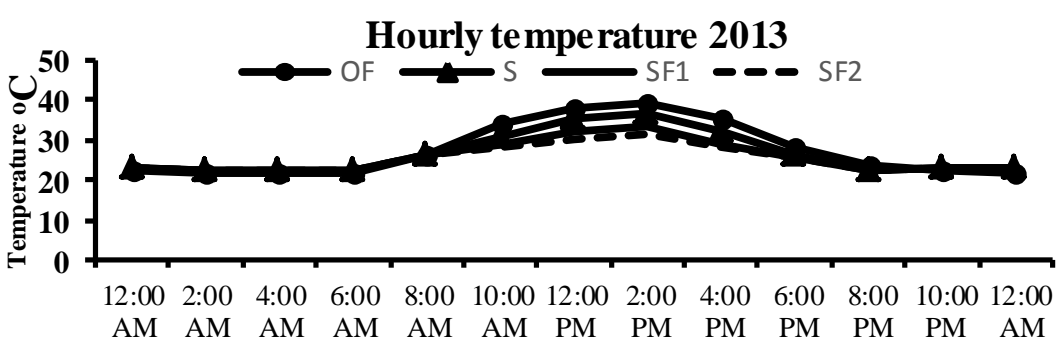

Time

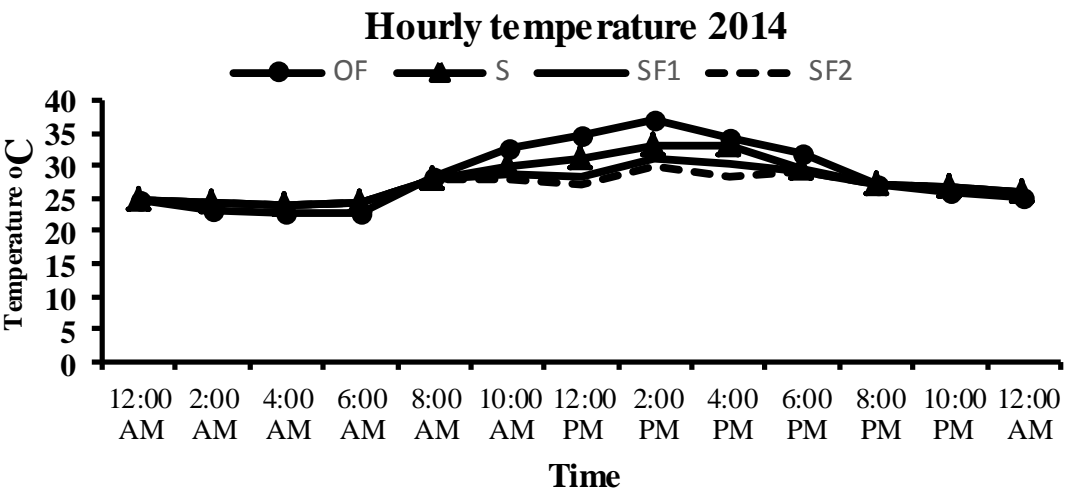

Fig. 1. Hourly temperature changes during the peak of flowering and fruit set at 26/7/2013 registered at open field (OF), shaded house (S), shaded house with fogging $10 \mathrm{~m} / \mathrm{h}$ (SF1) and shaded house with fogging $20 \mathrm{~m} / \mathrm{h}(\mathrm{SF} 2)$.

The data of monthly averages of maximum and minimum temperatures during the experimental periods indicate that the highest temperature averages accompanied with the lowest $\mathrm{RH} \%$ which were recorded in July and Aug. (Figs. 3, 4 \& 5). In all cases, the highest temperatures (maximum and minimum) were obtained from the open field which exceeded $35 / 22{ }^{\circ} \mathrm{C}$ during July and Aug. The shading and fogging contributed to decrease $4.5^{\circ} \mathrm{C}$ from the monthly average of maximum temperature and $1.7{ }^{\circ} \mathrm{C}$ from the minimum temperature. The fogging under shaded house was the most effective treatment for controlling the increase in temperature during the late summer season especially with increasing operating time to $20 \mathrm{~min} / \mathrm{h}$ (Fig. $3 \& 4$ ). The contrast was happened with RH\% which the lowest values were registered in the open field (Fig. 5). It was less than $60 \%$ in July and did not exceed $65 \%$ at the all season (from Jun. to Oct.). 
The RH\% under shaded house without fogging was $2.6 \%$ higher than the open field. Providing the shaded house by fogging system $(20 \mathrm{~min} / \mathrm{h})$ increased $\mathrm{RH} \%$ by $10.2 \%$.
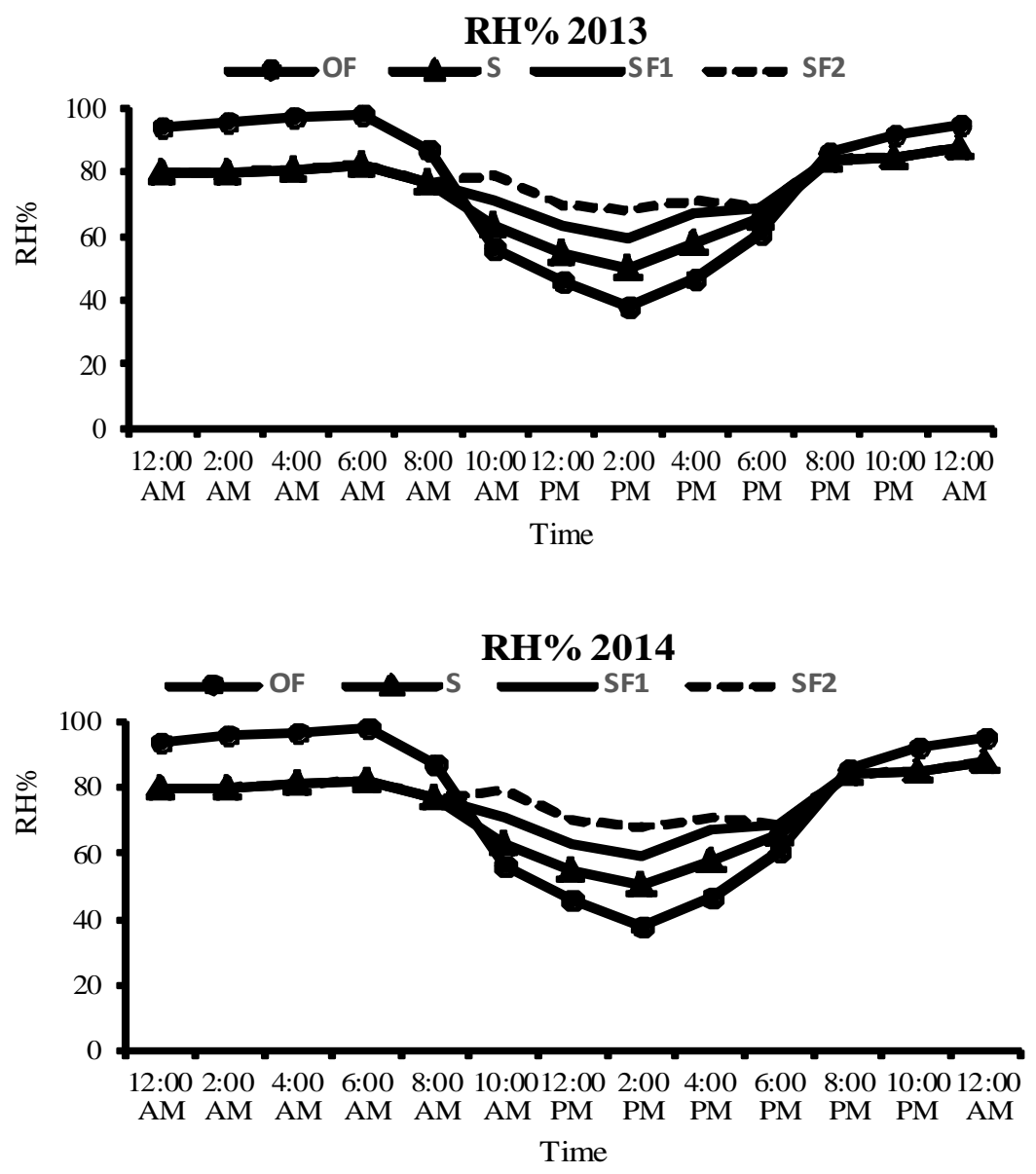

Fig. 2. Hourly relative humidity during the peak of flowering and fruit set at 26/7/2013 registered at open field (OF), shaded house (S), shaded house with fogging $10 \mathrm{~m} / \mathrm{h}$ (SF1) and shaded house with fogging $20 \mathrm{~m} / \mathrm{h}$ (SF2) 

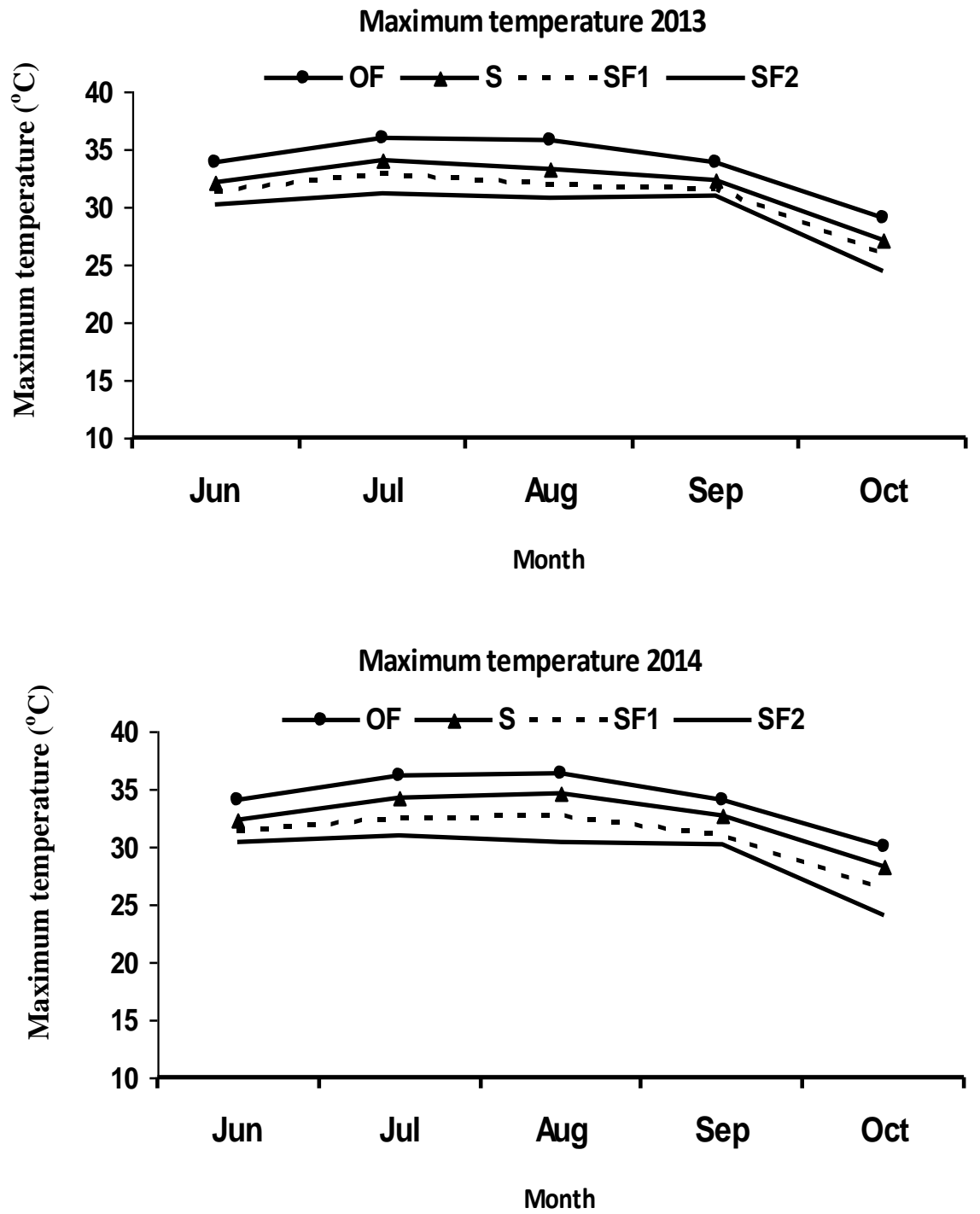

Fig. 3. Average monthly maximum temperature during the experiments period, registered at open field (OF), shaded house (S), shaded house with fogging $10 \mathrm{~m} / \mathrm{h}$ (SF1) and shaded house with fogging $20 \mathrm{~m} / \mathrm{h}$ (SF2) . 

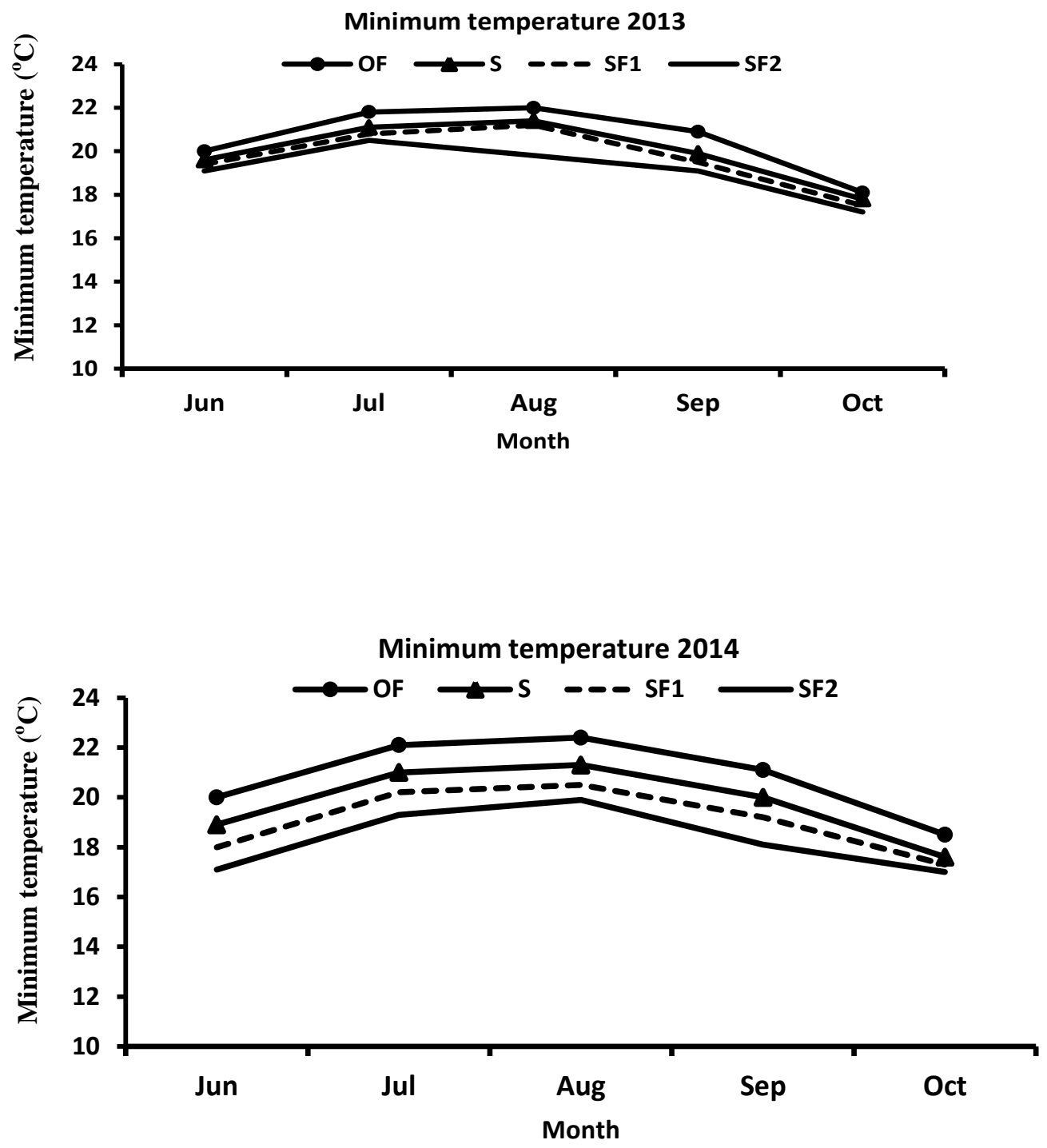

Fig. 4. Average monthly minimum temperature during the experiments period, registered at open field $(\mathrm{OF})$, shaded house (S), shaded house with fogging $10 \mathrm{~m} / \mathrm{h}$ (SF1) and shaded house with fogging $20 \mathrm{~m} / \mathrm{h}$ (SF2) 

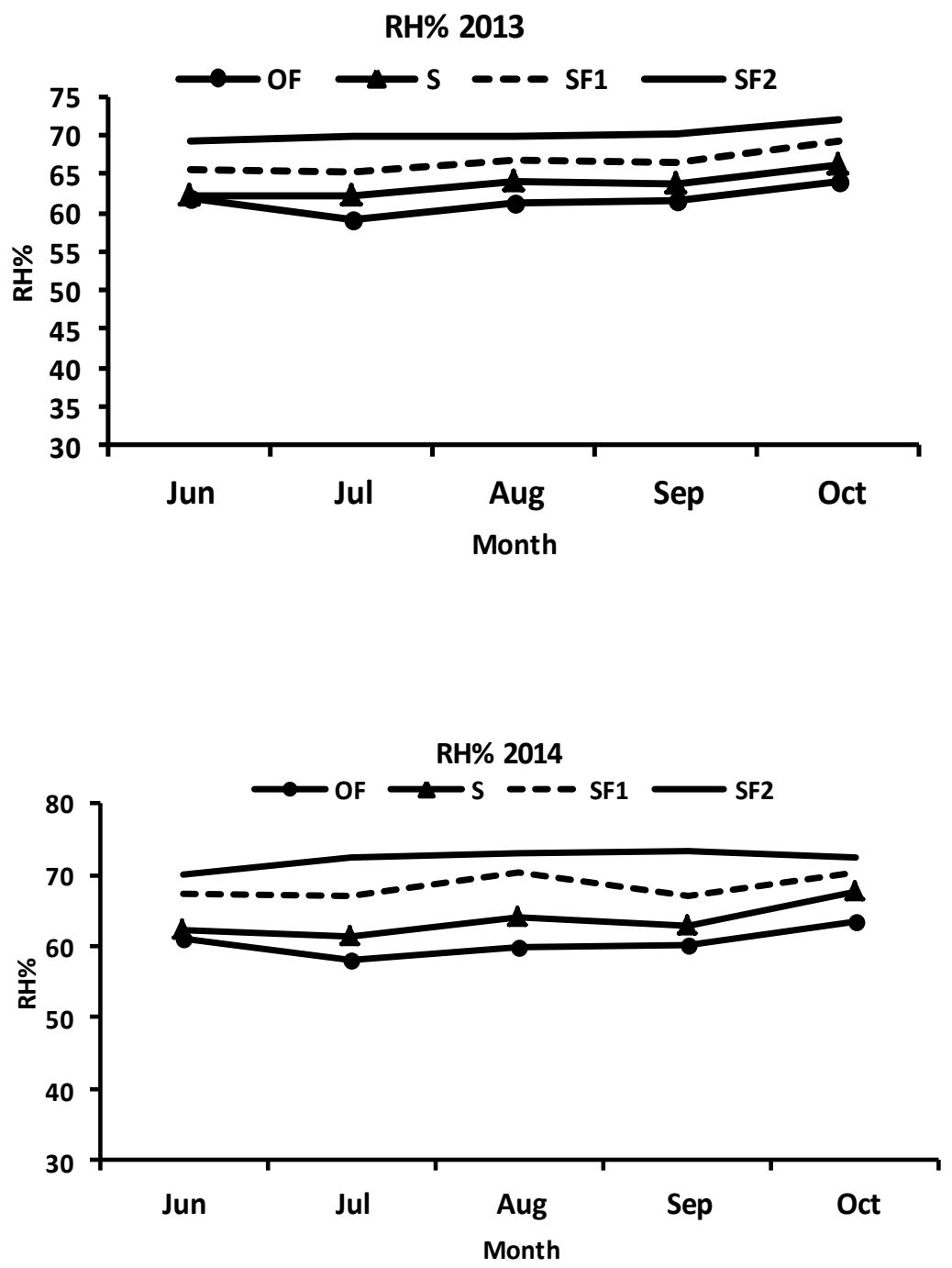

Fig. 5. Average monthly RH\% during the experiments period, registered at open field (OF), shaded house (S), shaded house with fogging $10 \mathrm{~m} / \mathrm{h}$ (SF1) and shaded house with fogging $20 \mathrm{~m} / \mathrm{h}$ (SF2) 


\section{Fruit set}

Fruit set data was presented in Table 1. Fruit set percentage was very low in the grown plants under the open field conditions which ranged from 51.4 to $53.6 \%$. Whereas, a significant increase was obtained from the grown plants under the shaded house. The use of fogging system under the shaded house achieved the highest fruit set percentage especially when the operating time increased from 10 to $20 \mathrm{~min} / \mathrm{h}$. The highest operating time gave fruit set percentage ranged from 80.3 to 80.7 in the first and second season, respectively.

TABLE 1. Effect of shading and fogging system on the percentage of fruit set, average fruit weight and percentages of marketable yield and fruit disorders of tomato.

\begin{tabular}{|c|c|c|c|c|}
\hline \multirow{2}{*}{ Treatment $^{\#}$} & Fruit set \% & \multirow{2}{*}{$\begin{array}{c}\text { Average fruit } \\
\text { weight }(\mathbf{g})\end{array}$} & $\begin{array}{c}\text { Marketable } \\
\text { yield }\end{array}$ & $\begin{array}{c}\text { Disorder } \\
\text { fruits }\end{array}$ \\
\cline { 3 - 5 } & & As percentage of the total yield \\
\hline \multicolumn{5}{|c|}{$\mathbf{2 0 1 3}$ season } \\
\hline Open field & $51.4 \pm 0.32 \mathrm{~d}$ & $60.8 \pm 0.44 \mathrm{~d}$ & $52.4 \pm 0.15 \mathrm{~d}$ & $44.6 \pm 0.32 \mathrm{a}$ \\
\hline Shading & $65.1 \pm 0.35 \mathrm{c}$ & $67.8 \pm 0.27 \mathrm{c}$ & $69.4 \pm 0.35 \mathrm{c}$ & $20.8 \pm 0.04 \mathrm{~b}$ \\
\hline $\begin{array}{c}\text { Shading + } \\
\text { fogging1 }\end{array}$ & $76.8 \pm 0.12 \mathrm{~b}$ & $73.0 \pm 0.20 \mathrm{~b}$ & $74.2 \pm 0.78 \mathrm{~b}$ & $.12 \mathrm{c} 12.0 \pm 0$ \\
\hline $\begin{array}{c}\text { Shading + } \\
\text { fogging2 }\end{array}$ & $80.3 \pm 0.21 \mathrm{a}$ & $77.4 \pm 0.79 \mathrm{a}$ & $77.4 \pm 0.41 \mathrm{a}$ & $10.3 \pm 0.11 \mathrm{~d}$ \\
\hline \multicolumn{5}{|c|}{$\mathbf{2 0 1 4}$ season } \\
\hline Open field & $53.6 \pm 0.21 \mathrm{~d}$ & $63.1 \pm 0.18 \mathrm{~d}$ & $55.4 \pm 0.86 \mathrm{c}$ & $38.9 \pm 0.43 \mathrm{a}$ \\
\hline Shading & $66.7 \pm 0.15 \mathrm{c}$ & $71.4 \pm 0.45 \mathrm{c}$ & $74 . \pm 0.12 \mathrm{~b}$ & $15.8 \pm 0.25 \mathrm{~b}$ \\
\hline $\begin{array}{c}\text { Shading }+ \\
\text { fogging1 }\end{array}$ & $78.3 \pm 0.22 \mathrm{~b}$ & $75.9 \pm 0.06 \mathrm{~b}$ & $75.9 \pm 0.46 \mathrm{ab}$ & $9.6 \pm 0.46 \mathrm{c}$ \\
\hline $\begin{array}{c}\text { Shading + } \\
\text { fogging2 }\end{array}$ & $80.7 \pm 0.22 \mathrm{a}$ & $78.5 \pm 0.29 \mathrm{a}$ & $77.3 \pm 0.54 \mathrm{a}$ & $7.6 \pm 0.11 \mathrm{~d}$ \\
\hline
\end{tabular}

${ }^{\#}$ Fogging system was operated $10 \mathrm{~min} / \mathrm{h}$ in fogging1 and $20 \mathrm{~min} / \mathrm{h}$ in Fogging2 and both operated from 10 am to $4 \mathrm{pm}$.

Different letters in the same column indicate that means are significantly different $(\mathrm{P}<0.05)$.

\section{Yield and its components}

The highest fruit yield was obtained under the shaded house with SF2 including: average fruit weight (Table 1) and marketable and total yield (Fig. 6). The treatments can be arranged from the highest as $\mathrm{SF} 2>\mathrm{SF} 1>\mathrm{S}>\mathrm{OF}$. Average fruit weight increased from 60.8- 63.1 $\mathrm{g}$ in the open field to $77.4-78.5$ $\mathrm{g}$ in the shaded house with SF2. SF2 treatment produced $4-4.3 \mathrm{~kg} / \mathrm{plant}$ of the total yield with $3.1-3.3 \mathrm{~kg}$ of marketable yield compared to $2.1-2.4 \mathrm{~kg}$ total yield and $1.1-1.3 \mathrm{~kg}$ marketable yield in the open field (Fig. 6). The marketable yield contributed to $77.3-77.4 \%$ from the total yield with SF2 compared to 52.4 - 55.4\% in the open field, while shaded house and FS1 were committed with intermediate values (Table 1). 

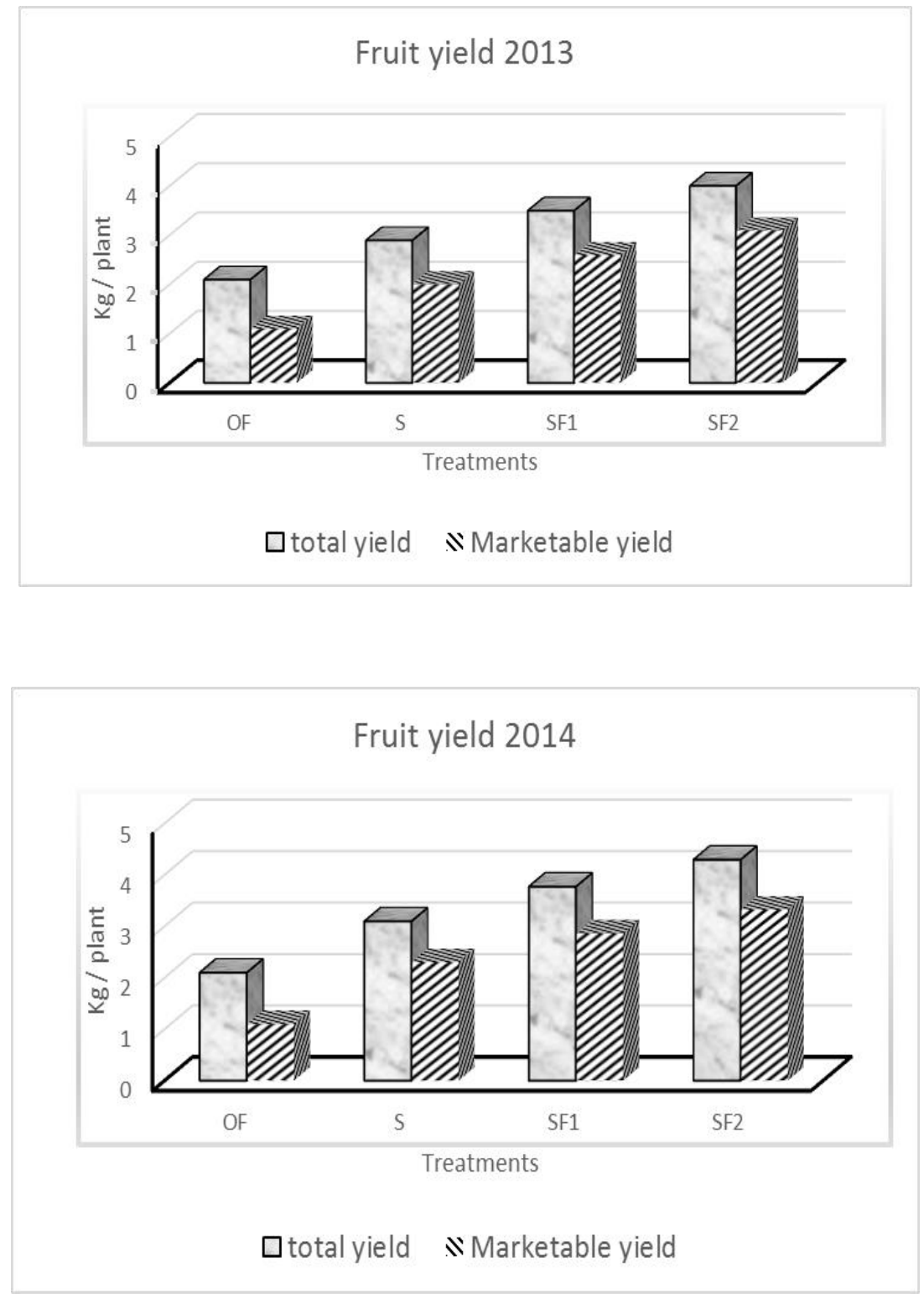

Fig. 6. Effect of shading and fogging system on tomato fruit yield (kg / plant), evaluated at open field (OF), shaded house (S), shaded house with fogging $10 \mathrm{~m} / \mathrm{h}$ (SF1) and shaded house with fogging $20 \mathrm{~m} / \mathrm{h}$ (SF2) 


\section{Fruit disorders}

The lower fruit disorders percentage reflected to higher marketable yield percentage (Table 1). SF2 decreased general fruit disorders percentage from being $38.9-44.6 \%$ in the open field to be $7.6-10.3 \%$. The main disorders were cracking, sunscald, blossom end rot, Puffiness, internal white tissues, blotchy and cat face, in order from the higher to the lower incidents (Table 2 ). The main fruits disorder was sunscald in the open field (comparing to the other disorders), it was fruit cracking in the shaded house although it was also lower than the open field. Significantly lower in fruits cracking was obtained under shaded house especially with fogging system without significant differences between the two studied operating systems. The cracking reduced from $8.1-9.1 \%$ in the open field to $2.4-2.9 \%$ in SF2. Although, there was a large portion of sunscald in the open field (10.1 $12.3 \%$ ), non was noticed in the shaded house. The fogging system under shaded house succeeded to reduce blossom end rot from $7.1-7.6 \%$ in the open field to $1.5-2.0$ with SF2 treatment. The same results were obtained in the other studied disorders which reduced puffiness from $4.6-5.1$ to $0.7-$ $1.6 \%$, the internal white tissues from 4.2 to $2.1-2.3$, the blotchy ripening from $2.8-3.1$ to $0.5-0.8$ and the cat face from $2.2-3.2$ to $0.5-0.9 \%$. However, shaded house and SF1 treatments resulted in intermediate values in all cases.

TABLE 2. Effect of shading and fogging system on the percentage of some tomato fruit disorders as a percentage of the total yield.

\begin{tabular}{|c|c|c|c|c|c|c|c|}
\hline Treatment $^{\#}$ & Cracking & Sunscald & BER* & Puffiness & IWT $^{\wedge}$ & Blotchy & Cat face \\
\hline \multicolumn{8}{|c|}{2013 season } \\
\hline OF & $9.1 \pm 0.09 \mathrm{a}$ & $12.3 \pm 0.09 \mathrm{a}$ & $7.6 \pm 0.18 \mathrm{a}$ & $5.1 \pm 0.05 \mathrm{a}$ & $4.2 \pm 0.65 \mathrm{a}$ & $3.1 \pm 0.01 \mathrm{a}$ & $3.2 \pm 0.06 \mathrm{a}$ \\
\hline S & $5.7 \pm 0.32 b$ & $0 \pm 0.00 \mathrm{~b}$ & $4.5 \pm 0.32 b$ & $2.9 \pm 0.09 \mathrm{~b}$ & $3.3 \pm 0.09 \mathrm{~b}$ & $2.0 \pm 0.06 \mathrm{~b}$ & $2.4 \pm 0.20 \mathrm{~b}$ \\
\hline SF1 & $3.4 \pm 0.15 \mathrm{c}$ & $0 \pm 0.00 \mathrm{~b}$ & $2.2 \pm 0.07 \mathrm{c}$ & $1.3 \pm 0.09 \mathrm{c}$ & $2.6 \pm 0.15 \mathrm{c}$ & $0.9 \pm 0.04 \mathrm{c}$ & $1.6 \pm 0.09 \mathrm{c}$ \\
\hline SF2 & $2.9 \pm 0.03 \mathrm{c}$ & $0 \pm 0.00 \mathrm{~b}$ & $2.0 \pm 0.06 \mathrm{c}$ & $1.6 \pm 0.24 \mathrm{c}$ & $2.3 \pm 0.12 \mathrm{~d}$ & $0.8 \pm 0.02 \mathrm{c}$ & $0.9 \pm 0.04 \mathrm{~d}$ \\
\hline \multicolumn{8}{|c|}{2014 season } \\
\hline OF & $8.1 \pm 0.49 \mathrm{a}$ & $10.1 \pm 0.06 \mathrm{a}$ & $7.1 \pm 0.04 \mathrm{a}$ & $4.6 \pm 0.15 \mathrm{a}$ & $4.2 \pm 0.10 \mathrm{a}$ & $2.8 \pm 0.04 \mathrm{a}$ & $2.2 \pm 0.09 \mathrm{a}$ \\
\hline S & $4.1 \pm 0.04 b$ & $0 \pm 0.00 \mathrm{~b}$ & $3.4 \pm 0.06 \mathrm{~b}$ & $2.4 \pm 0.06 \mathrm{~b}$ & $2.9 \pm 0.13 \mathrm{~b}$ & $1.8 \pm 0.02 b$ & $1.3 \pm 0.10 \mathrm{~b}$ \\
\hline $\mathrm{SF} 1$ & $2.9 \pm 0.35 \mathrm{c}$ & $0 \pm 0.00 \mathrm{~b}$ & $1.9 \pm 0.07 \mathrm{c}$ & $1.0 \pm 0.04 \mathrm{c}$ & $2.4 \pm 0.03 \mathrm{c}$ & $0.5 \pm 0.01 \mathrm{c}$ & $0.8 \pm 0.07 \mathrm{c}$ \\
\hline $\mathrm{SF} 2$ & $2.4 \pm 0.06 \mathrm{c}$ & $0 \pm 0.00 \mathrm{~b}$ & $1.5 \pm 0.02 \mathrm{~d}$ & $0.7 \pm 0.03 \mathrm{~d}$ & $2.1 \pm 0.04 \mathrm{~d}$ & $0.5 \pm 0.03 \mathrm{~d}$ & $0.5 \pm 0.02 \mathrm{~d}$ \\
\hline
\end{tabular}

\# OF = open field, $\mathrm{S}=$ shaded house, $\mathrm{SF} 1=$ shaded house with fogging system $(10 \mathrm{~min} / \mathrm{h})$ and SF2 = shaded house with fogging system $(20 \mathrm{~min} / \mathrm{h})$, fogging was operated from 10 am to $4 \mathrm{pm}$. $* \mathrm{BER}=$ blossom end rot. ${ }^{\wedge}$ IWT $=$ internal white tissue.

Different letters in the same column indicate that means are significantly different $(\mathrm{P}<0.05)$. 


\section{Discussion}

High summer temperature and low relative humidity in Mediterranean region especially during the day time of 10 am to $4 \mathrm{pm}$ are observed. The temperature can exceed $37^{\circ} \mathrm{C}$ and the $\mathrm{RH}$ could decrease than $40 \%$. In addition, the high spread of insects and related virus diseases reflected to the limits of tomato production at the late summer season in the open field. The net house can be used to prevent insect's entry and translocate viruses. Whereas, the grown plants under high temperature conditions in the open field suffer from physiological and biochemical stresses. Possible biochemical and/or physiological processes affected by high temperature are photosynthetic enzyme activity, membrane integrity, photophosphorylation, and electron transport in chloroplast, stomatal conductance to $\mathrm{CO}_{2}$ diffusion and photoassimilate translocation which all dealing finally with tomato yield reduction (Dinar and Rudich, 1985). The results in Table 1 indicate a significant reduction in fruit set percentage in the open field (heat stress conditions). This reduction could be explained according to Kuo et al. (1986) who suggested the mechanism of proline accumulation in tomato leaf tissue at high temperature. Proline thus causes the depletion of proline in the reproductive tissue, thereby seriously reducing pollen formation or viability. In the same line, Sato et al. (2006) reported that failure of tomato fruit set under a moderately increased temperature above optimal is due to the disruption of sugar metabolism and proline translocation during the narrow window of male reproductive development. It is also had negative effect on release of pollen grains, fruit set and fruit production (Sato et al., 2000). The favorable effect of shading on fruit set percentage and fruit production (Table 1) may attributed to the reduction in hourly and average monthly temperature (Fig. $1 \& 3$ ) which ameliorated heat stress on the plant. A reduction in insect and virus infections was also noticed inside the shaded house as a role of anti-insect net cover which all reflected to plant health. It is also reported that shading resulted in high nutrient uptake and photosynthesis rate and in turn more fruits with high weights (Milenković et al., 2012 and El-Bassiony et al., 2014). The effect of shade on transpiration may be as important for fruit growth as its effect on photosynthesis and carbohydrate status (Medrano et al., 2004 and Gent, 2007). The high light intensity in the open field can lead to several disorders in development and appearance of tomato fruit that affect quality (Dorais et al., 2001). Pearce et al. (1993) noted that under high irradiance during the day, the rate of fruit swelling was reduced because the plants exposure to water stresses through the high transpiration rates. The high irradiance and air temperature and their combined effects could be reasons for sunscald injury and alter metabolism leading uneven ripening (Adegoroye \& Jolliffe, 1987 and Gent, 2007). The obtained results in Table 2 show that field-grown fruits exposed to sunlight had more cracks than shaded fruits. This result is supported by WhaleyEmmons and Scott (1997) findings who obtained 49\% of cracking fruits in the open field versus $20 \%$ under shading. It could be explained as exposure of fruit to sunlight could change the water potential of the fruit directly and cause the skin to crack as a result of heating of the fruit surface. The midday decrease in 
plant water potential should be less for plants grown under shade which may be an important factor in controlling cracking under shade. Moreover, shading clearly would ameliorate heat stress in proportion to the reduction in sunlight intensity. Secondarily, plant leaf area tends to increase under low-light conditions, and shading may result in better coverage of the fruit by leaves hence decrease sunscald. The reduction in fruit set under heat stress could be as a result of the leak in pollen grain viability which was improved by applying fogging system under shaded house (Harel et al., 2013). Moreover, the heat stress in the open field was also reported as a reason for high physiological disorders, i.e., Cracking, sunscald, blossom end rot and puffiness (Milenković et al., 2012).

The RH\% can be another reason for the higher fruit set under shading with or without fogging compared to the open field. It is clear from Fig. 2 that RH\% reached to less than $40 \%$ at afternoon which could be a reason for low fruit set in the open field compared to higher values inside the shaded house with or without fogging which it was higher than $60 \%$. These results are supported by Huang et al. (2011) who tested tomato pollen quality and fruit set at several air humidity levels and found that increased RH (60-70\%) improved pollen and fertilization in comparison with $30-40 \%$ RH. The results of Harel et al. (2014) were that increased $\mathrm{RH} \%$ (from $50 \%$ without fogging to $75 \%$ with fogging) was found to be positively correlated to pollen viability which reflected to high fruit set. They added that even relatively small increases of $2{ }^{\circ} \mathrm{C}$ in the mean daily temperature can cause a yield reduction of up to $60 \%$ which these findings are in agreement with the obtained results. These results indicate that the global worming even relatively small increase in mean daily temperature could affect tomato production in the open field if unsuitable practices were taken. Leyva et al. (2013) summarized the benefits of fogging systems in the improved environmental conditions, besides promoting the highest activities of ROSscavenging enzymes, the redox state of the ascorbate, and a low proline: free putrescine ratio, which would explain the increase in commercial weight of fruit by $21 \%$ to $17 \%$, with respect to un-fogging. These explanations could be support the high fruit weigh and yield in the obtained results with fogging system (Table 1 \& Fig. 6).

\section{Conclusion}

- Growing tomato in the open field during the late summer season exposures for heat stress accompanied with a reduction in relative humidity especially from 10 am to $4 \mathrm{pm}$.

- $\quad$ Growing tomato under shaded net house with 35\% shading ameliorate heat stress and caused an improvement in fruit set and yield with low physiological disorders.

- The use of fogging system especially with operating time $20 \mathrm{~min} / \mathrm{h}$ increased the efficiency of the shaded house and improved the microclimate conditions which appeared in high yield and low fruit disorders.

Egypt. J. Hort. Vol. 42, No. 2 (2015) 
- It seems that the moderate reduction in mean daily air temperature and increasing $\mathrm{RH} \%$ under fogging conditions enabled the tomato to better manage with heat stress and to improve fruit set and yield.

\section{References}

Adegoroye, A.S. and Jolliffe, P.A. (1987) Some inhibitory effects of radiation stress on tomato fruit ripening. J. Sci. Food Agr., 39, 297-302.

Alessandri, A., DeFelice, M., Zeng, N., Mariotti, A., Pan, Y., Cherchi, A., Lee, J., Wang, B., Ha, K., Ruti, P. and Artale, V. (2014) Robust assessment of the expansion and retreat of Mediterranean climate in the $21^{\text {st }}$ century. Scientific Reports, 4, 1-8.

Dinar, M. and Rudich, J. (1985) Effect of heat stress on assimilates partition in tomato. Ann. Bot., 56, 239-249.

Dorais, M., Papadopoulos, A.P. and Gosselin, A. (2001) Greenhouse tomato fruit quality. Hort. Rev. (Amer. Soc. Hort. Sci.) 26, 239-319.

El-Aidy, F.A. and Sharaf-Eldin, M.A. (2015) Modifying microclimatic conditions in plastic walk-in tunnels through solar energy system for improving yield and quality of four sweet pepper hybrids. Plasticulture, 134, 6-22.

El-Bassiony, A.M., Fawzy, Z.F., Aiad, G.S. and Ghoname, A.A. (2014) Mitigation of high temperature stress on growth, yield and quality of tomato plants by different shading level. Middle East J. of Appl. Sci., 4 (4), 1034-1040.

FAO (2013) Good Agricultural Practices for greenhouse vegetable crops: Principles for Mediterranean climate areas. www.fao.org/3/a-i3284e.

Gent, M.P.N. (2007) Effect of Degree and Duration of Shade on Quality of Greenhouse Tomato. Hort. Sci., 42 (3), 514-520.

Harel, D., Fadida, H., Slepoy, A., Gantz, S. and Shilo, K. (2014) The Effect of Mean Daily Temperature and Relative Humidity on Pollen, Fruit Set and Yield of Tomato Grown in Commercial Protected Cultivation. Agronomy, 4, 167-177.

Harel, D., Fadida, H., Gantz, S., Shilo, K. and Yasuor, H. (2013) Evaluation of Low Pressure Fogging System for Improving Crop Yield of Tomato (Lycopersicon esculentum Mill.): Grown under Heat Stress Conditions. Agronomy, 3, 497-507.

Huang, Y., Li, Y. and Wen, X. (2011) The effect of relative humidity on pollen vigor and fruit setting rate of greenhouse tomato under high temperature condition. Acta Agric. Boreali-Occident. Sin., 11, 1-20.

Kuo, C.G., Chen, H.M. and Ma, L.H. (1986) Effect of high temperature on proline temperature content in tomato floral buds and leaves. J. Amer. Hort. Sci., 111 (5), 746-750.

Leyva, R., Constán-Aguilar, C., Blasco, B., Sánchez-Rodríguez, E., Soriano, T. and Ruíz, J.M. (2013) A Fogging system improves antioxidative defense responses and productivity in tomato. J. Amer. Soc. Hort. Sci., 138, 267-276. 
Leyva, R., Constán-Aguilar, C., Sánchez-Rodríguez, E., Romero-Gámez, M. and Soriano, T. (2015) Cooling systems in screenhouses: Effect on microclimate, productivity and plant response in a tomato crop. Biosystems Engineering, 129, 100-111.

Leyva, R., Constán-Aguilar, C., Blasco, B., Sánchez-Rodríguez, E., Romero, L., Soriano, T. and J.M. Ruíz (2014) Effects of climatic control on tomato yield and nutritional quality in Mediterranean screen house. J. Sci. Food Agric., 94 (1), 63-70.

Mahato, A. (2014) Climate Change and its Impact on Agriculture. Inter. J. Sci. Res. Publications, 4 (4), 1-6.

Medrano, E., Lorenzo, P., Guerro, M.C.S., Garcia, M.L. and Caparros, I. and Giminez, M. (2004) Influence of external greenhouse mobile shading on tomato crop transpiration. Acta Hort., 659, 195-199.

Milenković, L., Ilić, Z.S., Šunić, L., Trajković, R., Kapoulas, N. and Đurovka, M. (2012) Reducing of tomato physiological disorders by photoselective shade nets. $47^{\text {th }}$ Croatian and $7^{\text {th }}$ International Symposium on Agriculture. Opatija, Croatia. Symposium Proceedings, pp. 419-423.

Montero, J.I (2006) Evaporative cooling in greenhouses: Effect on microclimate, water use efficiency and plant response. International symposium on greenhouse cooling: methods, technologies and plant responses. Acta Hort., 719, 373-383.

Pearce, B.D., Grange, R.I. and Hardwick, K. (1993) The growth of young tomato fruit II: Environmental influences on glasshouse crops grown in rockwool or nutrient film. J. Hort. Sci. 68, 13-23.

Sato, S., Peet, M.M. and Thomas, J.F. (2000) Physiological factors limit fruit set of tomato (Lycopersicon esculentum Mill.) under chronic, mild heat stress. Plant, Cell \& Enviro., 23 (7), 719-726.

Sato, S., Kamiyama, M., Iwata, T., Makita, N., Furukawa, H. and Ikeda, H. (2006) Moderate increase of mean daily temperature adversely affects fruit set of Lycopersicon esculentum by disrupting Specific physiological processes in male reproductive development. Ann Bot., 97 (5), 731-738.

Shehata, S., Elsagheer, A.A., El-Helaly, M.A., Saleh, S.A. and Abdallah, A.M. (2013) Shading effect on vegetative and fruit characters of tomato plant. J. Appl. Sci. Res., 9 (3), 1434-1437.

Whaley-Emmons, C.L. and Scott, J.W. (1997) Environmental and physiological effects on cuticle cracking in tomato. J. Amer. Soc. Hort. Sci., 122, 797-801.

Zaki, M.S., AboaSedera, F.A., Badr, L.A., Sadek, I.I. and El-Sawy, A.M. (2014) Effect of some climatic factors and irrigation regimes on tomato growth and chemical constituents. Annals of Agric. Sci., Moshtohor, 52 (3), 1-9. 


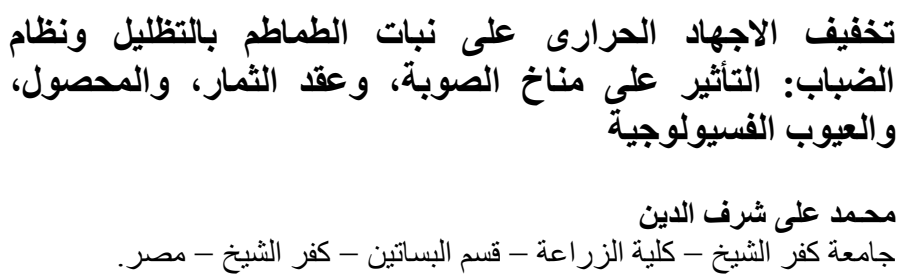

تم دراسة تأثير الاجهاد الحرارى على محصول الطماطم خلال العروة الصيفية

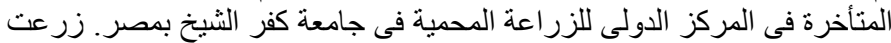

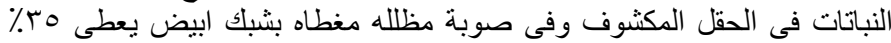

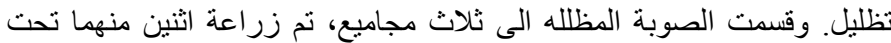

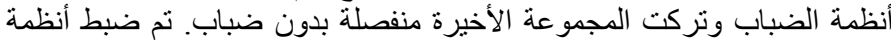

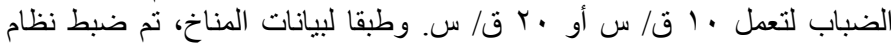

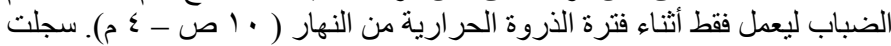

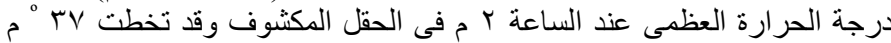

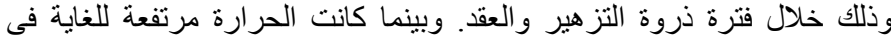

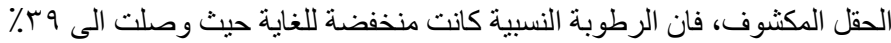

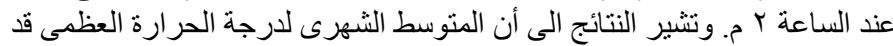

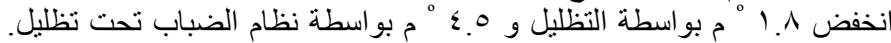

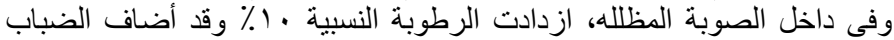

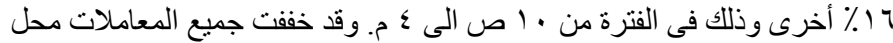

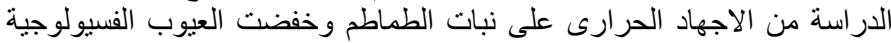

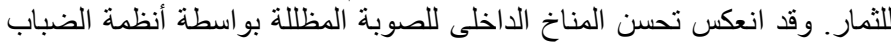

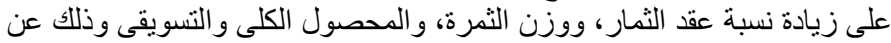

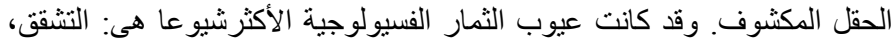

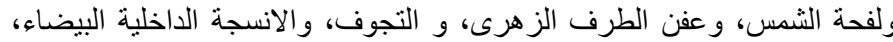

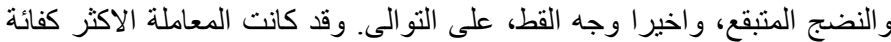

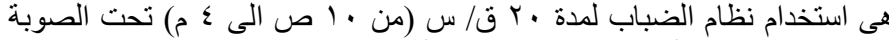

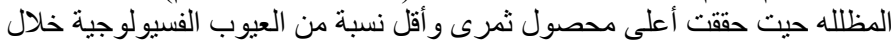

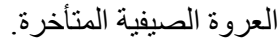

